\title{
The Effect of Solvency, Firm Size, Age Companies on Audit Report Lag in Indonesian Company
}

\author{
Ustman \\ School of Accounting, Madura University, Jl Raya Panglegur Km 3.5 Pamekasan, Indonesian
}

\begin{abstract}
Audit report lag is the time span for completing an audit of annual report conducted by the auditor. The purpose of this study is to find evidence empirical factors affecting the audit report lag. Audit report lag is very important because it can have an impact on the timeliness of accounting information presentation to be used as a decision maker by managers or external parties. There is three factors can affect audit report lag, namely solvency, firm size, and age companies. The population of this research is trading companies listing on the Indonesia Stock Exchange. The number of samples obtained was 32 companies that have been determined by purposive sampling method. Test result shows that the solvency and age variables of the company have no effect against audit report lag. The firm size affects the audit report lag.
\end{abstract}

Keywords: Audit Report Lag, Solvency, Firm Size, Age Companies

DOI: $10.7176 /$ RJFA/11-2-02

Publication date: January $31^{\text {st }} 2020$

\section{INTRODUCTION}

In the era of globalization, the world economy has experienced a lot of development on a national and international scale which makes the world boundaries blurred so that the more tightening competition between companies. To face these challenges, then company management is trying to get more capital to fund activities operations that can not only be fulfilled by relying on funding sources internal and debt. Another way to meet the needs of these funds can be done by selling ownership of the company's shares to investors.

Under the regulations of the Financial Services Authority the company is required to submit the annual report of the issuer or public company no later than the end of April after the financial year ends. As stated in the Statement of Financial Accounting Standards that the financial statements must also meet four qualitative characteristics that make financial statements useful for the wearer, i.e. understandable, timely, relevant, reliable and comparable.

To produce relevant financial statement information, there are several constraints, one of which is time. The fulfillment of audit standards by the auditor can have an impact on the length of the audit report completion, but also has an impact on improving the quality of the audit. Abdulla (1996) argues that the shorter time and the date of publication of the financial statements, the greater the benefits that can be derived from information on these financial statements. He confirmed that the delay in release financial statements are likely to increase uncertainty related to decisions made based on information contained in the financial statements.

Iskandar and Trisnawati (2010) explain the time difference between the report dates the financial date of the auditor's report indicates the length of time for completion an audit called audit report lag. The longer an audit report lags, the better it will be negative impact. The length of time for audit completion (audit report lag) will be affect the timeliness in releasing audited financial statement information. The delay in the publication of financial statement information has an impact on the level uncertainty of the decision taken.

Bustamam and Maulana 2010, Kartika (2011) found an intermediate influence solvency or the proportion of debt in the audit report lag. But research from Iskandar and Trisnawati, (2010) and Juanita (2012) failed to find an effect between solvency with audit report lag. Research from Puspitasari (2012) states that total assets affect audit report lag. Likewise, the Modugu study (2012) which states that total assets affect audit lag report. But research from Iskandar and Trisnawati (2010) did not find the effect between total assets and audit report lag.

Petrolina (2007), shows that company age has a negative effect on audit report lag. The longer the company's life, the audit reporting period will be faster and vice versa. However, from the research of Lianto and Kusuma (2010) shows the results that the age of the company affects the audit report lag. Company that have long stood in general has expanded with the opening business branches in several regions both domestically and abroad. The large scale of operations shows the number of checks that need to be done by the auditor. This will certainly extend the audit process and affect audit report lag.

Previous studies show different results, so research on the factors that affect audit report lag is still very interesting to study. Solvency shows the company's ability to pay throughout obligations, both short and long term if the company is dissolved (liquidated). The size of the company shows the greater the value of the company's assets, the shorter the audit report lag and vice versa. Large companies tend to be more quickly complete the audit process. The age of the company reflects the permanent company survive and be proof that the company is able to compete and can take business opportunities that exist in the economy. 
Trading companies were chosen as research objects because there were only a few researching. Iskandar and Trisnawati (2010), Subekti and Widiyanti (2004), Ahmad and Kamarudin (2003) explains the differences in industrial characteristics it can cause differences in the time span for completing the audit. One type of easy company run is a trading company because its business activities are limited to buying the merchandise then resells it without changing the shape of the item. Therefore the trading company cycle has a unique character that is only found in a trading company. In Indonesia, many trading companies have gone public in Indonesia stock exchange. this motivates researchers to conduct research on the effect of solvency, firm size, age companies on audit report lag in Indonesian company.

\section{LITERATURES REVIEW AND HYPOTHESIS DEVELOPMENT}

\subsection{Theoretical Framework}

Timeliness is an important qualitative attribute of financial statements that are requires that information be available to users as quickly as possible. Delay in reporting can reduce the value of information and document relevance. Whittred, (1980); Givoly and Palmon, (1982); Carslaw and Kaplan, (1991) say the length of the audit is an important determinant that affects the timing of earnings announcements has motivated recent research on audit delays.

Givoly and Palmon (1982) analyzed the timeliness and content of information from the report yearly and examine their relationship with certain company attributes. They tested Beaver's (1968) suggestion that good news was released, bad news was systematically delayed, using the relative size of probability and the absolute and relative time measure.

Aryaningsih and Budiartha (2014) stated that the solvency variable is influential to audit delay, because when a company has a high level of solvency, the audit delay conducted by the auditor indicated increasingly longer. Audit the account debt requires a long time because they have to find the source of the cause of the high the proportion of debt held by the company and takes a lot of time in confirm debtor parties related to the company.

Carslaw and Kaplan (1991) further test audit delay in New Zealand. The results of his research analyzed with a separate sample, that size The company does not significantly affect audit delays for managers that are controlled company. Apparently, company size is associated with other balancing factors Adverse impact on audit delays for manager-controlled companies but not for owner-controlled companies.

\subsection{Hypothesis Development}

\section{Solvency}

The solvency variable is often referred to as the leverage ratio is the sum of the proportions debt held by the company. Solvency can also be interpreted as a comparison between the amount of debt with the amount of equity owned by the company. When the company has a proportion of debt that is more than the amount of equity, the auditor will require more time in auditing the company's financial statements due to the complexity of the debt account audit procedure and the discovery of more audit evidence complex against the company creditors (Aryaningsih \& Budiartha, 2014). Bustamam and Maulana 2010, Kartika (2011) found an influence between solvency or debt proportion on audit report lag.

\section{H1. Solvency effect on the audit report lag}

Firm Size

There are several studies that have found that there is a significant influence between firm size and audit delays in developed and developing countries (Newton \& Ashton, 1989; Davies \& Whittred, 1980; Carslaw \& Kaplan, 1991; Garsomble, 1981; Gilling, 1977 and Abdulla, 1996). The majority of previous studies have used total assets to measure company size.

The characteristics of a good financial report are the timeliness of reporting, then audits are conducted by auditors so that they can issue audited financial statements. Companies that have go public use the capital market as a means to obtain funding sources. But the auditor needs time to be able to publish the results examination in the form of his opinion.

Total assets are categorized as firm size. The size of the firm size can influence the timeliness of financial statements. that asset company-owned can be in the form of cash, merchandise, and non-cash items tangible and has value (Warren, James, \& Jonathan, 2008). Companies that have large assets are believed to be able to complete the audit process faster. Because large companies have good internal control compared to small companies. So can encourage auditors to complete the audit process on time (Iskandar \& Trisnawati, 2010). Research from Puspitasari (2012) states that total assets affect audit report lag. Likewise, the Modugu study (2012) which states that total assets affect audit report lag.

\section{H2. Total assets affect the audit report lag} Age Companies

The long-standing company has generally expanded with opened a new branch to develop its business in several regions. So the large scale of this operation indicates that many checks need to be carried out auditor, plus the level 
of complexity of the transaction. So that it can extend the process audits that affect audit report lag. Lianto and Kusuma (2010) stated age the company has an effect on audit report lag.

\section{H3. Age Companies Affect the audit report lag}

\section{RESEARCH METHODS}

This type of research is quantitative, with an explanatory approach. Object of research This was done at the Indonesia Stock Exchange. The population of this research is all companies registered trade on the Indonesia Stock Exchange in the period 2014 to 2018, totaling 45 companies. Determination of the sample is done using the method purposive sampling. The number of samples selected was 32 companies that met the requirements criteria for each period.

This study uses three independent variables, namely solvency, total assets, and age of the company. Solvency is measured by a DER (debt to equity ratio) that is obtained from the total liabilities divided by total equity (Kasmir 2008: 159).

$$
\text { Solvency }=\frac{\text { Total Liability }}{\text { Total Equity }} \times 100 \%
$$

According to Arens and Lobbecke (2005), firm size can be valued from total assets that company owned. Firm size is calculated based on the natural logarithm $(\mathrm{Ln})$ of total assets of the company. Finally, the age of the company is calculated from the length of the company it goes public (sundari, 2017). The last financial year (research) is reduced the year it first went public.

The dependent variable in this study is audit report lag. Audit report lag is measured with days needed to obtain an independent auditor's report, which is per 31 December to the date stated on the independent auditor's report (Subekti and Widiyanti, 2004). The analysis technique used in this study is multiple linear regression. But before the classic assumption test which consisted of the normality test, multicollinearity, heteroscedasticity, and autokoleration.

The multiple linear regression estimation model used in this study are:

$$
\mathrm{Y}=\alpha+\beta 1 \mathrm{X} 1+\beta 2 \mathrm{X} 2+\beta 3 \mathrm{X} 3+\mathrm{e}
$$

Note:

$\mathrm{Y} \quad=$ Audit report lag

$\alpha \quad=$ Constant

$\mathrm{X} 1=$ Solvency

$\mathrm{X} 2 \quad=$ Firm size

$\mathrm{X} 3=$ Age companies

$\beta 1-\beta 3=$ Estimated coefficient

e $\quad=$ error

4. DATA ANALYSIS AND RESULT

4.1 Descriptive Statistics Test Results

Table 1. Descriptive Statistics

\begin{tabular}{lllll}
\hline & Minimum & Maximum & Mean & Std. Deviation \\
Solvency &, 02807 & 10,07400 & 1,6590395 & 2,26891119 \\
Firm Size & 23,7295 & 33,1425 & 28,012238 & 2,1192736 \\
Age Companies & 1,00 & 26,00 & 13,5312 & 9,10152 \\
Audit ReportLag & 45,6667 & 110,6667 & 76,791667 & 13,7075837 \\
\hline
\end{tabular}

Source: data processed

Solvency as measured by the Debt to Equity Ratio (DER) is the ratio between total debt to equity. In table 1 can be seen the average capital structure at a trading company on the Indonesia Stock Exchange of the Year 20142018 amounted to 1.6590395 and the standard deviation of 2.2689119 where standard the deviation is greater than the average value. In addition, the value can also be known solvency of 0.02807 and the highest value of 10.07400 . This shows in part Large trading companies on the Indonesia Stock Exchange use debt as a source of funding.

The size of the company in table 1 can be seen that the average growth of companies in trading companies on the Indonesia Stock Exchange in 2014-2018 amounted to 28.012238 and the standard deviation of 2.1192736 where the standard deviation is smaller than the average. In the table also can be seen the lowest firm size value of 23.7295 and the highest value of 33.1425 .

Company age in table 1 can be seen that the average profitability of companies in trading companies on the Indonesia Stock Exchange in 2014-2018 was 13.5312 and the standard deviation was 9.10152 where the standard deviation value was smaller than the average value. The table also shows that the lowest age of the company is 1.00 and the highest is 26.00 .

Audit report lag in table 1 can be seen that the average trading company on the Indonesia Stock Exchange in 2014-2016 was 76.791667 and the standard deviation was 13.7075837 , where the standard deviation value was 
smaller than the average value. The table also shows the lowest audit report lag value of 45.66677 and the highest 110.66667.

\subsection{Multiple Linear Regression}

Table 2. Multiple Linear Regression

$\begin{array}{lc}\text { Y= }+\beta_{1} X_{1}+\beta_{2} X_{2}+\beta_{3} X_{3}+e & \\ \text { Independent Variable } & \text { Value } \\ \text { The constant } & 150,8^{* *} \\ \text { (value t) } & 4,825 \\ \text { Solvency } & -0,483 \\ \text { (value t) } & -0,464 \\ \text { Firm Size } & -2.527^{*} \\ \text { (value t) } & -2,277 \\ \text { Age Companies } & -0,178 \\ \text { (value t) } & -0,684 \\ \text { R Square } & 0.179 \\ \text { Adj. R Square } & 0,091 \\ \text { F Stat } & 2,029\end{array}$

Dependent Variable $=$ Audit report Lag

Sample (n) $\quad=32$

$* *$ Significant at alpha $1 \%, * 5 \%$

Source: data processed

Table 2 shows the results of the calculation of solvency to audit report lag, namely sig $\mathrm{t}(0.464)>\alpha(0.05)$. So that $\mathrm{HO}$ is accepted and Ha rejected does not affect the solvency of the audit report lag in trading companies listed on the Indonesian Stock Exchange (BEI) in 2014-2018 These results different from studies conducted by Lianto and Kusuma (2010) who studied the factors that influence the audit report lag partially profitability with a significance value of 0.003 , solvency with a significance value of 0.023 and the age of the company with a significance value of 0.045 affect the audit report lag.

In the research results of the calculation of company size on audit report lag is $\operatorname{sig} \mathrm{t}(0.031)<\alpha(0.05)$. So that $\mathrm{H} 0$ is rejected and $\mathrm{Ha} 2$ accepted that the size of the company's effect on audit report lag trading companies listed on the Indonesian Stock Exchange (BEI) in 2014-2018. The results study was not consistent with research conducted by Lianto and Kusuma (2010) which examines the factors that affectaudit lag reportwhere the size of the company with a significance of 0.368 and the type of industry 0.548 has no significant effect on audit report lag.

In this study the results of the calculation of the age of the company against audit report lag is $\operatorname{sig} t(0.500)>$ $\alpha(0.05)$. So that $\mathrm{H} 0$ is received and Ha rejected company that age does not affect the audit report lag in trading companies listed on the Indonesian Stock Exchange (BEI) in 2014-2018. Firm size in this study had no effect on the audit report lag. Based on the data it can be seen that there are two types of company size in outline, namely large and small sized companies. Large companies have an average audit report lag of 73 days while smaller companies have an average number of audit report lags of 77 days. This proves that thetime span audit report lag between large and small companies is not much different, not only large companies, but small companies also tend to get pressure to submit financial statements in a timely manner. The pressure can come from the investors themselves or from OJK through regulations on the delivery of financial statements on time. The results of this study are different from the research conducted by Lianto and Kusuma (2010) who examined the factors that influence the audit report lag in which the age of the company with the significance value of 0.045 affects the audit report lag.

\subsection{Effect of Solvency, Firm Size and Company Age Simultaneously Against Audit Report Lag}

In relation to the length of audit report lag, it certainly affects the component in fieldwork lag order to check the amount of debt owed to creditors, all debt agreements, and so on. The more the amount of debt, the longer the audit process. The process certainly requires extra time for the auditor in the audit process. The auditor certainly also checks compliance with the suitability of the debt agreement and the contract agreement. Solvency shows the company's ability to meet all financial obligations when the company is liquidated. A high proportion of debt to total assets will affect the liquidity associated with issues going concern, which in turn requires more careful auditing. Measuring a company can be based on the book value of assets owned by the company.

The larger the size of a company, the more complicated the process of conducting audits. Regarding components in the audit report lag, company size affects all components both scheduling, fieldwork, and reporting lag. The age of this company is calculated from the first time a company is listed on the Indonesia Stock Exchange until the year of research. Where does the company's age have an influence in the component audit report lag 
related scheduling lag is entirely the responsibility of the company in preparing financial statements. The three explanations of the independent variables prove that the time span of audit report lag between large and small companies is not much different not only large companies, but small companies also tend to get pressure to submit financial statements in a timely manner. The pressure can come from the investors themselves or from OJK through regulations on the submission of financial statements on time.

The results of hypothesis testing showed that the value of sig (0133) $>\alpha(0.05)$, it can be concluded that $\mathrm{H} 0$ is accepted and Ha rejected namely solvency, size and age of the company does not influence simultaneously toward to the audit report lag in trading companies listed on the Stock Indonesian Stock Exchange (IDX) in 20142018. The results of this study differ from research conducted by Andika (2015) which examines the effect of profitability, solvency, liquidity, company size, audit opinion on Based audit report lag on the Indonesia Stock Exchange. On the results of research conducted, the conclusion is drawn that all independent variables are simultaneously namely profitability, solvency and liquidity, company size and audit opinion with a significance value of 0.001 , which significantly influence the audit report lag.

\section{CONCLUSION AND RECOMMENDATION}

Based on the results of data analysis and discussion in the previous chapter, then at This research concludes as follows:

a. The results of the calculation of solvency to audit report lag are sig $\mathrm{t}(0.646)>\alpha(0.05)$. So that $\mathrm{H} 0$ is accepted and Ha rejected does not affect the solvency audit report lag on trading companies listed on the Indonesia Stock Exchange (IDX) in 2014-2018.

b. The results of the calculation of company size on audit report lag are sig $\mathrm{t}(0.031)<\alpha(0.05)$. So that H0 is rejected and Ha accepted that firm size to audit lag reports on trading companies listed on the Stock Exchange Indonesia (IDX) in 2014-2018.

c. The results of the calculation of company age on audit report lag are sig t $(0.500)>\alpha(0.05)$. So that $\mathrm{H} 0$ is accepted and Ha denied that age does not affect the company to audit lag reports on trading companies listed on the Stock Exchange Indonesia (IDX) in 2014-2018.

d. The results showed the value of sig $(0.133)>\alpha(0.05)$, it can be concluded that H0 is accepted and Ha rejected namely solvency, size and age the company has no simultaneous effect on the audit report lag on trading companies listed on the Indonesia Stock Exchange (IDX) in 2014-2018.

Based on the results of the discussion and conclusions obtained in this study, then suggestions can be given as follows:

1. For companies are expected to further enhance their capabilities in managing finances as a source of funding for corporate activities as well as being able control management performance so as to create a conducive state for the development of the company. Especially in the disclosure of financial statements that must be considered so that errors do not occur in the recording so auditor performance becomes faster.

2. For further research, it is expected to use a different sample, extend the study period, as well as using other factors (both internal or external), because it is very possible other variables are not included in this study affect the audit report lag.

\section{REFERENCES}

Abdulla, J. Y. A. (1996). "The Timeliness of Bahraini Annual Reports", Advances in International Accounting, Vol. 9, pp. 73-88

Ahmad, R. A. R. Dan Kamarudin, Khairul. A. 2003. Audit Delay and The Timeliness of Corporate Reporting: Malaysia Evidence. Published Dissertation. MARA University of Technology.

Andika, Windu. 2015. Pengaruh Profitabilitas, Solvabilitas, Likuiditas, Ukuran Perusahaan, Opini Audit Terhadap Audit Report Lag (Studi Empiris di Perusahaan Jasa Yang Terdaftar di Bursa Efek Indonesia); Universitas Sanata Dharma, Yogyakarta.

Arens, Alvin A dan Lobbecke James K. 2005. Auditing An Integrated Approach; Eight Edition New Jersey Prentice Hall Inc.

Aryaningsih, Ni Nenga. D. dan Budiartha, I Ketut. 2014. Pengaruh Total Aset, Tingkat Solvabilitas dan Opini Audit pada Audit Delay. Jurnal Ilmiah Akuntansi dan Bisnis. Vol. 7, No. 3 Hal 747-647

Bustamam., Maulana Kamal. 2010. Pengaruh Leverage, Subsidiaries dan Audit Complexity Terhadap Audit Delay. Jurnal Telaah dan Riset Akuntansi. Vol. 3, No. 2, hal: 110-122

Carslaw dan Kaplan. 1991. An Examination of Audit Delay: Further Evidnece From New Zealand; Accounting and Business Research Vol 22 No 82 Hal 21-32.

Davies, B and Whittred G. P (1980). The Association between Selected Corporate Attributes and Timeliness in Corporate Reporting: Further Analysis. Abacus, June, pp. 48-60.

Garssombke, H. P. (1981) “The Timeliness of Corporate Disclosure”, in J. K. Courtis (ed.) Communication via Annual Reports, AFM Exploratory Series No. 11, University of New England, Armidale, New South Wales, 
pp. 204-218.

Gilling M. D (1977) “Timeliness in Corporate Reporting: Some Further Comment”, Accounting and Business Research, Winter, pp. 35-50.

Givoly , G and Palmon, D (1982) "Timeliness of Annual Earnings Announcements: Some Empirical Evidence”, The Accounting Review, Vol. LVII. No. 3 July, pp. 486-508.

Iskandar, M. Januar dan Trisnawati, Estralita. 2010. Faktor-Faktor Yang Mempengaruhi Audit Report Lag Pada Perusahaan Yang Terdaftar Di Bursa Efek Indonesia; Jurnal Bisnis Dan Akuntansi Vol 12 No 3 hal 175-186.

Jensen, M C dan Meckling, W H. 1976. Theory of The Firm: Managerial Behavior, Agency Cost And Ownership Structure; Jurnal of Financials Economics Vol 3 No 4 Hal 305-360.

Juanita, Greta. 2012. Pengaruh Ukuran Kantor Akuntan Publik, Kepemilikan, Laba Rugi, Profitabilitas dan Solvabilitas Terhadap Audit Report Lag; Jurnal Bisnis dan Akuntansi Vol 14 No 1 Hal 31-40.

Kartika, Andi. 2011. Faktor-Faktor yang Mempengaruhi Audit Delay pada Perusahaan Manufaktur yang Terdaftar di BEI. Jurnal Dinamika Keuangan dan Perbankan. Vol. 3, No. 2, Hal: 152-171

Kasmir. 2008. Analisis Laporan Keuangan; Penerbit PT Raja Grafindo Persada, Jakarta.

Lianto, Novice dan Kusuma, B. Hartono. 2010. Faktor-Faktor Yang Berpengaruh Terhadap Audit Report Lag; Jurnal Bisnis dan Akuntansi Vol 12 No 2 Hal 97-106.

Modugu, Prince Kennedy., Emmanuel Eragbhe., Ohiorenuan Jude Ikhatua. 2012. Determinants of Audit Delay in Nigerian Companies: Empirical Evidence. Research Journal of Finance and Accounting. Vol. 3, No. 6

Newton, J. D., and Ashton, R. H. (1989) The Association Between Audit Technology and Audit Delay", Auditing: A Journal of Practice And Theory, Vol. 8, No. 1, pp. 22-37

OJK. 2016. Keputusan Ketua Otoritas Jasa Keuangan Nomor 29/POJK 04/2016.

Petrolina, Thio Anastasia. 2007. Analisis Skala Perusahaan, Opini Audit, dan Umur Perusahaan atas Audit Report Lag. Akuntabilitas. Vol. 6, No. 2. Hal: 129-141

Puspitasari, Elen., Anggraeni Nurmala Sari. 2012. Pengaruh Karakteristik Perusahaan terhadap Lamanya Waktu Penyelesaian Audit (Audit Delay) pada Perusahaan Manufaktur yang Terdaftar di Bursa Efek Indonesia. Jurnal Akuntansi dan Auditing. Vol. 9, No. 1

Subekti, Imam dan Widiyanti, N. Wulandari. 2004. Faktor-faktor Yang Berpengaruh Terhadap Audit Delay di Indonesia; Simposium Nasional Akuntansi VII Hal 991-1002.

Sundari, R. Fajar. 2017. Pengaruh Tipe Auditor, Umur Perusahaan, Ukuran Perusahaan, Profitabilitas, Leverage, dan Jenis Industri Terhadap Pengungkapan Modal Intelektual (Studi Empiris Pada Perusahaan Manufaktur Yang Terdaftar di BEI Tahun 2012-2014); Publikasi Ilmiah Universitas Muhammadiyah, Surakarta.

Warren, Carl S., James M. Reeve, and Jonathan E. Duchac. 2008. Principle of Accounting. United State of America: South Western Part of Thomson Corp.

Whittred, G., (1980) “Audit qualification and the timeliness of corporate annual reports", The Accounting Review, Vol. 55 (July), pp.563-577. 